\title{
ANGLO-SAXON IMPERIALISM THROUGH CULTURAL GOODS: TITLES SUGGESTED FOR YOUNG READERS IN PORTUGAL
}

\author{
Maria João Ferro* \\ Instituto Superior de Contabilidade e Administração de Lisboa/ \\ Centro de Linguística da Universidade Nova de Lisboa
}

\begin{abstract}
Translation plays a vital role in the current multilingual and multicultural society. It is a fundamental infrastructure of globalization, functioning as an essential tool for the circulation of information, knowledge, and culture. Although English can be considered a lingua franca in certain sectors of society, the role of translation has not lessened with its rise. In fact, translation is a strong indicator of the relationships established between countries: international translation flows depend on the (im)balances of power in the world. In this paper I analyse relevant data to ascertain the weight of works originally written in English and translated into Portuguese, resorting to the national reading plan (PNL). After briefly addressing the influence of geopolitics in the trade of cultural goods and describing the world system of translation, I analyse the list of 345 books suggested in the national reading plan for 12-15 year olds. Almost half of these books are translations; however, this does not imply
\end{abstract}

\footnotetext{
* Maria João Ferro is a senior lecturer at the Lisbon School of Accountancy and Administration, Lisbon Polytechnic Institute (ISCAL-IPL), where she teaches and coordinates several courses, such as Business English, Legal English, Technical Writing, Portuguese for Foreign Students, and Research Methodologies. She is a researcher at NOVA CLUNL and holds a PhD in Linguistics (Terminology) from Universidade NOVA de Lisboa (UNL). Her research interests are Literary Translation, Technical Translation and Terminology, Languages for Specific Purposes, and Research Methodologies for the Social Sciences.
} 
that the list is sufficiently multicultural, quite on the contrary as it shows the dominance of books written in English. A lot more can be done to diversify the source languages and expose Portuguese young readers to a wider variety of cultures.

Keywords: Translation. Multilingualism. Multiculturalism. Cultural Goods.

\title{
IMPERIALISMO ANGLO-SAXÓNICO ATRAVÉS DOS BENS CULTURAIS: LEITURAS SUGERIDAS PARA JOVENS EM PORTUGAL
}

\begin{abstract}
Resumo: A tradução desempenha um papel crucial na nossa sociedade multilingue e multicultural. Constitui uma infraestrutura fundamental da globalização e funciona como uma ferramenta essencial para promover a circulação de informação, conhecimento e cultura. Embora o inglês possa ser considerado uma lingua franca em certos setores da sociedade, o papel da tradução não diminuiu com a sua ascensão. De facto, a tradução é um forte indicador das relações que se estabelecem entre os vários países: os fluxos de tradução internacionais dependem dos (des)equilíbrios de poder no mundo. Neste artigo, analiso dados relevantes para perceber o peso que têm as obras originalmente escritas em inglês e traduzidas para português, recorrendo ao Plano Nacional de Leitura (PNL). Depois de abordar brevemente a influência da geopolítica no comércio de bens culturais e de descrever o sistema mundial de tradução, analiso a lista de 345 títulos sugerida no PNL para o terceiro ciclo, que cobre a faixa etária dos 12-15 anos. Quase metade desses títulos são traduções; contudo, isso não significa que a lista seja suficientemente multicultural, uma vez que, pelo contrário, mostra a dominância das obras escritas em inglês. Há muito que se pode fazer para diversificar as línguas de partida e expor os jovens leitores portugueses a uma maior variedade de culturas.
\end{abstract}

Palavras-chave: Tradução. Multilinguismo. Multiculturalismo. Bens Culturais.

\section{Introduction}

In a multilingual and multicultural network society, translation plays an essential role as mediator between languages and cultures. In fact, translation is a fundamental infrastructure of globalization, 
functioning as an essential tool for the circulation of information, knowledge, and culture among communities that do not share the same language. As Parks $(1998,26)$ puts it,

the modern world would be inconceivable without translation. The whole culture of the Renaissance was based on the translation of the Greek and Roman classics; modern western religion is entirely based on translations of the Bible [...] and its importance is likely to increase, rather than decrease, in the future, until and unless there is a single world language.

Parks is being playful, obviously, because the idea of a single language is not without problems and would hardly be accepted by the population in general. Language conveys a lot more than simple information and relies on its symbolic content. The choice of a language is never incidental and carries with it the full weight of the culture, or cultures, it is associated with. Although English can indeed be considered a lingua franca in certain sectors of society ${ }^{1}$ - e.g. in the financial markets, in international organizations, in civil aviation, in pop culture to a certain extent - the role of translation has not lessened with its rise (e.g. Sapiro 2014). While many choose to use English as a means to disseminate their message and thus reach a larger audience than they would in their mother tongue, most people would rather have access to products, services, and even cultural content in their own languages. This tension between two contradictory forces to which Pym (2006) calls the "diversity paradox" - convergence to English as a global communication tool and divergence to autochthonous languages as a commercial strategy - has boosted translation and localization services.

${ }^{1}$ And even this is open to debate. 
The predominance of English together with a few other - mostly European - dominant languages over global informational flows echoes the current geopolitical inequalities (Bielsa 2005, 2012). Speakers of dominant languages are able to transmit information and knowledge, while speakers of peripheral languages are frequently limited to the passive attitude of recipients. This phenomenon is particularly evident in the cultural industries, namely literature, cinema, and music: statistics show that English-speaking countries, specifically the United States of America (US) and the United Kingdom (UK), have a much higher volume of exports of cultural goods than imports. According to Heilbron (2010), in the US and in the UK, the percentage of published books that were not originally written in English is around 2 to 4 per cent. This number has even given rise to the birth of a movement fostered by the University of Rochester in the US entitled Three Percent, ${ }^{2}$ whose aim is to raise awareness to modern and contemporary international literature in the US, providing valuable information to readers, publishers, and translators. In the UK the situation is similar, although this percentage is somewhat higher and is now exceeding 4 per cent according to a study conducted by the Mercator Institute for Media, Languages and Culture (Donahaye 2012). This study has also shown that publishers in the UK and Ireland find publishing translations a risky venture and ultimately rely on government grants to do it. This distrust is mostly associated with the attitude the British population usually displays towards foreign languages, coupled with the predominance of English as a lingua franca that makes many English-speaking people believe they do not need any other language to communicate anywhere in the world.

Conversely, Portuguese audiences tend to accept foreign fiction and non-fiction works quite well. In fact, traditionally, the opposite bias seems to prevail since Portuguese people in general tend to consider what comes from the outside better, or trendier, or more appealing than what is produced inside our borders. This

${ }^{2}$ Available at http://www.rochester.edu/College/translation/threepercent/. 
is particularly evident in the case of cultural goods, e.g., in the number of film sessions exhibited in Portugal: in 2014, 21.8 per cent of all the films exhibited were from the US; however, these represented over half of the market share with 56.4 per cent of all sessions and 56.9 per cent of tickets sold (INE 2015). Portugal is not alone here since Hollywood blockbusters usually take the world by storm: almost all of the top selling films for many years now have been made in the US (Mélitz 2007).

Starting from the notion of linguistic imperialism (Phillipson 1992) and in view of the empirical evidence of the predominance of English-language culture in modern society (particularly in the case of Portugal), in this paper I analyse relevant data to ascertain the weight of works originally written in English and subsequently translated into Portuguese, specifically resorting to the national reading plan - "Plano Nacional de Leitura", henceforth PNL a government initiative that aims to promote reading and writing skills and habits. I analyse the list of 345 books suggested for the third cycle of schooling (12 to 15 year olds) to understand the extent to which foreign authors (and associated cultures) have managed to populate that list. The remainder of the paper is organized as follows: in the next section, I briefly address the influence of geopolitics in the trade of cultural goods; after that I describe the methodology that supports this study; the following section presents and discusses the findings of this study; finally, I conclude with some final remarks and future research avenues.

\section{Cultural goods and geopolitics}

Cultural goods convey a symbolic content and are usually protected by intellectual property rights. Given their exceptional nature, they cannot be subject to the same market rules that apply to other goods and services in general, although the trade of cultural goods routinely crosses borders. In fact, due to the recent advances in communication and information technologies 
of the past four decades, cultural goods are now disseminated over a wider area than ever. This, however, has not contributed to promote multiculturalism as much as it could, since US- and UKmade cultural goods have found a way to successfully permeate modern culture.

UNESCO's Universal Declaration on Cultural Diversity has a section dedicated to "Cultural Diversity and Creativity" that intends to contribute to the protection of all forms of heritage and cultural goods. Articles 8 and 9 of the Declaration particularly recognize that cultural goods and services are of a unique kind, they are "vectors of identity, values and meaning, [and] must not be treated as mere commodities or consumer goods" (UNESCO 2002, 5). Cultural policies must therefore protect the circulation and dissemination of ideas and works, endeavouring to promote diversity. Articles 10 and 11 in the next section call attention to the "current imbalances in flows and exchanges of cultural goods and services at the global level" (5) and urge that public policies be made in partnership with the private sector and civil society since " $[\mathrm{m}]$ arket forces alone cannot guarantee the preservation and promotion of cultural diversity" (5). Governments have been employing strategies to protect cultural diversity, but not always with the desired outcome - Perona (2010), for example, effectively argues that broadcasting quotas harm diversity instead of promoting it as they were intended to.

Translation is a strong indicator of the relationships established between countries: international translation flows depend on the (im)balances of power in the world. Heilbron $(1999,2010)$ describes what he calls the "international system of translation" roughly based on de Swaan's world language system (de Swaan, 2001). Working with data gathered from the Index Translationum, a database maintained by UNESCO that contains information on published translations in over one hundred countries from 1979 to the present time, Heilbron draws a four-tier structure, whose central position - more precisely, hypercentral position - is occupied by English, which dominates the global market of translations, with 55 
to 60 per cent of all book translations made from books originally written in English. The central position in Heilbron's model is currently occupied by French and German, each with a share of around 10 per cent of the translation market. These are followed by some seven or eight semi-central languages, each with a share of 1 to 3 per cent of the world market of translations. The last tier is occupied by all the other languages, each with a share of less than 1 per cent of the global translation market. This last tier is where we find Portuguese, together with other widely spoken languages, such as Chinese and Arabic, and all the other languages with a lower number of speakers.

This hierarchy, however, is not fixed and the position of each language can change over time, often gradually and following geopolitical changes. The loss of status of Russian after the fall of the Berlin Wall in 1989 is a good example of that change: in a decade or so, Russian slipped from a central to a semi-central position, which, in turn, allowed German to rise to that vacant spot.

The international system of translation implies that the more central the position of a language is, the larger the potential market for the authors who choose to write in that language will be. Authors who write in the hypercentral language are widely translated, while those who write in peripheral languages are not. Looking at the list of the top 50 translated writers worldwide according to Index Translationum, we find that 62 per cent of those writers were either born in an English-speaking country or chose to write in that language; 14 per cent write in French, 10 per cent in German, 6 per cent in Russian, 2 per cent in Spanish, and the remaining 6 per cent include Danish, Swedish, and Ancient Greek. (If we take a look at the most translated authors in Portugal and also according to the Index Translationum, we are going to find a similar picture: almost 60 per cent of those authors were born in English-speaking countries.) We have to look a bit further down the list of the top translated writers worldwide to find the first Portuguese-speaking author but not much: Paulo Coelho ranks 57 in the list, which is quite a feat for an author who writes in Portuguese. The next 
Portuguese-speaking author in the list is José Saramago, at No 222. Paulo Coelho is, in fact, one of the exceptions to the rule, since he fares far better than his language of choice would lead anyone to believe. In fact, "today it's possible to say that he [Paulo Coelho] owns as much symbolic capital as if he wrote in the hyper-central language" (Werner 2009, 46).

Public policies, however, seem to have forgotten translation and the enormous power it has to forge cultural identities. Almost twenty years ago Parks drew attention to the need to find out who is reading what in order to understand how such readings can influence self-perception: "If history is any guide, what a given society chooses to translate at any given time provides a clue as to the sort of society it is about to become" (Parks 1998, 30). Given his first-hand knowledge, the author also summarised the main consequences for Italian of the mass consumption of translated texts, which can easily be transposed to Portuguese:

i. the influence on language itself in terms of syntax and vocabulary;

ii. the development of popular literature hampered by the preference of publishers for foreign works and the requirement of any native attempt to conform to the established foreign standards;

iii. moving popular taste from native authors to those that belong to the globally dominant culture;

iv. gradually changing worldviews influenced by foreign models.

These consequences are already noticeable in our culture. For example, the influence of English syntax is overtly evident in the following verses of a mildly famous song entitled "Dizer que não" [Say no] by a Portuguese contemporary artist named Dengaz: "Mas na verdade eu também sei / Que sou do tipo que só dou valor àquilo que tenho / Quando fico sem". The last word in the excerpt, "sem" [without], is a preposition, and prepositions are never used at the 
end of a sentence in Portuguese, contrary to English where that is fairly common.

Translated works in 2013 accounted for almost a quarter of all the books published in Portugal (INE 2014), which highlights the importance of the selection of the books to be translated since these will be responsible for the construction of foreign stereotypes (Venuti 1998). According to the Index Translationum, from the 11,855 translated works in the category "Literature" published in Portugal in 2013, 55 per cent were originally written in English.

This is not a surprising number when we take into consideration the fact that language policies in Portugal have emphasised the importance of English in the past forty years. As a result of these policies the most widely learned foreign language in Portugal is currently English. And although language learning is a dynamic affair that depends on the strategic view of the government of the country, based on what the respondents to the Eurobarometer study (EC 2012) stated, English will continue to be the first option as regards foreign language learning in Portugal for the next generations. Portuguese respondents answered that English is the most useful language for their personal development (53 per cent), while 87 per cent of the respondents stated that English is the most useful language for children to learn for their future. The latter question is interesting because French (the most widely studied language in Portugal three generations ago) still comes second (32 per cent), followed by Spanish (10 per cent), German ( 5 per cent), and Chinese (4 per cent).

However, language skills do not rank high in the priorities of Portuguese respondents - 61 per cent answered that they do not speak any foreign language well enough to have a conversation. From those that answered that they do speak at least one foreign language, the ranking is the same as above: English (27 per cent), French (15 per cent), Spanish (10 per cent), and German (1 per cent). These language skills are not as developed as in other countries (Portugal comes third from the bottom together with the UK when considering the percentage of people that are able to maintain a conversation in at least one foreign language). 
These numbers result from the path chosen by decision-makers in terms of foreign language policies that tend to focus on a single international communication language, i.e., English, rather than promoting multilingualism from an early age.

Although Mélitz (2015) agrees that in certain cases - such as large international meetings with members from many different countries - having a working language such as English makes things easier, he is baffled by the dominance of the language in cultural areas, namely music, the film industry and best-selling books. Referring to the role of English as a lingua franca in the world today, the author finds evidence of such supremacy in the singles top chart since 1942, where only four singles from the ones that sold over five million copies were not sung in English. ${ }^{3}$ The same happens in the film industry where not a single film can be found in the top 500 that is not spoken in English. Parks had also recognized that the so-called "McDonaldization" of society is taking place not only through fast food but also through the invasion of foreign markets by American comic books, magazines, soap operas and best-sellers, and goes as far as to say that "most of the elements of the modern popular mythology derive from English and American sources" (Parks 1998, 28). What would our world be without superheroes, Mickey Mouse, or young sorcerers?

A quick look at the PNL list shows that many of the works suggested for children to read are translations from foreign titles. ${ }^{4}$ This is good news for the promotion of multiculturalism, given that Portuguese children are encouraged to come into contact with other different cultures. However, a closer look at the names reveals that a large number of the authors in the list come from an English-speaking country, which undermines the multicultural approach. This was the starting point for this research, in which I tried to quantify the presence of works originally written in English in the PNL.

\footnotetext{
${ }^{3}$ Mélitz does not contextualize these findings, but he is referring to the global influence of the English language in the music industry.

${ }^{4}$ We can gather this not only from the names of the authors, but also from the information provided on the list itself that states the name of the translator in such cases.
} 


\section{Methodology}

This study was based on the national reading plan, PNL, which presents suggestions for class and independent reading according to the children's ages. PNL's principal aim is to contribute to improve the literacy levels of Portuguese people by creating the necessary conditions to encourage reading and thus gradually enable people to have access, understand, and be able to interpret information from various sources, as well as to promote the enjoyment of reading as a leisure activity.

Every year, in association with the "Ler + Escolas" programme, PNL publishes reading lists of recommended titles for each age group, starting with 6-12 month-old babies up until adulthood. The main sections are: suggestions to be read aloud to pre-schoolers, books to be read in class, books to be read independently, and further suggestions for the older ones. The books contained in these lists were selected by a panel of experts based on different competence levels, as well as on the quality of the work itself, the accuracy of the translation, and the overall aesthetic value of the volume.

For this study, I selected the set of books targeted at children aged 12-15 because these correspond to formative years when children have already cemented their reading skills and developed their own taste: they usually know what they like to read and make their reading choices accordingly. Furthermore, these years correspond to a full cycle of studies - "Terceiro ciclo", literally the third cycle - and as such constitute a unit that can be analysed together.

After retrieving the list from PNL's website ${ }^{5}$, the first step was to compile a database that included the title of the book and the author's name, both collected from PNL's list of suggestions for the third cycle of schooling, which also includes the publisher's name and the

\footnotetext{
${ }^{5}$ This list is available at http://www.planonacionaldeleitura.gov.pt/ but it changes every year. At the time I started this study, I had access to the list of titles suggested for the $2015 / 2016$ school year. Currently, there is a new list online $(2016 / 2017)$, which contains some differences. I believe it would be interesting to further this study with a diachronic analysis of those differences.
} 
International Standard Book Number (ISBN). These two last items were discarded since they would not be necessary for the analysis, but were used whenever there was a decision to make on whether two books by the same author and with a similar title in Portuguese were, in fact, two translations of the same original title - e.g., Por favor, não matem a cotovia published by Difel and Mataram a cotovia published by Relógio D'Água Editores are two different translations of the same book, To Kill a Mockingbird by Harper Lee. In these cases, one translation was counted and not two.

After the full set of titles suggested for the third cycle of schooling was complete, their authors were researched in order to ascertain their nationality, which provided a clue as to the language in which the book was originally written and the country where it might have originally been published. ${ }^{66}$ With that information, I then searched the original title of the book and the country where it was first published to confirm the language in which it was written.

The titles in the list were distributed into seven numbered language categories: (1) Portuguese, (2) English, (3) French, (4) Spanish, (5) German, (6) Italian, and (7) Other. The result of this categorization can be seen in Table 1 below.

Table 1 Number and percentage of titles divided by language

\begin{tabular}{|l|l|l|l|}
\hline Cat. & Language & No. of titles & $\begin{array}{l}\text { Percentage } \\
\text { of the total }\end{array}$ \\
\hline 1 & Portuguese & 176 & 51.0 \\
\hline 2 & English & 111 & 32.2 \\
\hline 3 & French & 24 & 7.0 \\
\hline 4 & Spanish & 10 & 2.9 \\
\hline 5 & German & 7 & 2.0 \\
\hline
\end{tabular}

\footnotetext{
${ }^{6}$ Some authors, particularly in the case of hyphenated identities, pose categorization problems. In these cases, I relied on their working language (mostly based on the original language of the book included in the PNL and where it was first published). Therefore, Ilse Losa, for example, although born in Germany was classified as Portuguese.
} 


\begin{tabular}{|l|l|l|l|}
\hline 6 & Italian & 6 & 1.7 \\
\hline 7 & Other & 11 & 3.2 \\
\hline & TOTAL & 345 & \\
\hline
\end{tabular}

Table 1 shows the number of titles originally written in each language and the percentage that those titles represent taking into account the total number of works, i.e., all the 345 titles.

\section{Results and Discussion}

Works originally written in Portuguese make up a little over half of the whole list with 51 per cent of the total. And works published in Portugal take the lion's share of that number with 160 books, or 90.9 per cent of the total titles originally written in Portuguese. However, even though Portuguese is a pluricentric language, i.e. a language with more than one standard variety, this category does not show much variety: only nine books were originally published in Brazil, four in Angola, and three in Mozambique.

The second major group is, unsurprisingly, composed of English-language books. These make up 32.2 per cent of the total number of books listed in the PNL for the third cycle of schooling, which represents 65.7 per cent of all the books originally written in a foreign language. From the nations that have supplied these English-language titles, two stand out: the UK and the US - the former accounts for 50.5 per cent (56 titles) of this group and the latter represents 35.1 per cent (39 titles). The remaining 14.4 per cent of the English-language titles are composed of six books from South Africa, five from Ireland, four from $\mathrm{Canada}^{7}$, and one from Australia.

\footnotetext{
${ }^{7}$ In the case of Canada we controlled for the English/French dichotomy: all the Canadian titles in the PNL list for 2015/2016 were originally written in English.
} 
In line with the trend indicated in the Eurobarometer study (EC 2012) - i.e. French comes second as regards the respondents' perception of the usefulness of the language and the number of people who claim to be able to maintain a conversation in that language - French constitutes the third most important group: the list contains 24 titles originally published in France, which represents 21.6 per cent of all the foreign titles. According to the data available on the Index Translationum, 18 per cent of the top 50 writers translated in Portugal write in French.

Books written in Spanish come fourth in the list, but these make up less than 10 per cent of all the foreign titles. Here we can find some variety, since five books were originally published in Spain, two in Colombia, two in Chile, and one in Peru. Coincidentally, three other books were originally published in Spain but in different languages: two in Galician and one in Basque. These were accounted for in the "Other" category.

German and Italian books have almost the same representativeness, with only one book separating them: seven books in the list were originally published in Germany and six in Italy. Their weight in the overall list is lower, while German books represent 6.3 per cent of all the foreign books, Italian books account for only 5.4 per cent.

The last category, i.e. "Other", contains eleven books from six different countries: China, Greece, Israel, Russia, Sweden, and Spain (the aforementioned Basque and Galician originals). Apart from Spain, the other countries have supplied only one book to this list, except for Sweden, which is represented by four books.

In view of this scenario, I believe that the list of works suggested by the PNL for the third cycle of compulsory education could do more to promote a multicultural worldview. Children are biased towards the cultural realities they come into contact with. Broadly speaking, children aged 12-15 are mostly encouraged to read either books written in Portuguese and first published in Portugal or books written in English and mostly published in the US and in the UK. Let us not forget that English titles in this list make up a third of the total number of works (Portuguese included) and two thirds 
of the translated works alone. This does not leave much room for other languages and associated cultures to contribute to shape the worldviews of our children.

Multiculturalism is thus being hindered by the choices made and suggested for these children to read. Clearly market forces are playing their part here and the US and the UK economic agents profit from the hypercentral position the English language has not only in the international translation market, but also in the global society as a whole. However, even considering solely the titles originally written in Portuguese, there could be a greater variety of countries of origin, given that early contact with other Portuguese language standards and the cultures they convey would contribute to raise awareness to different cultures and open up the children's minds to other worldviews mostly shaped with the same language. I believe this would go a long way to create closer ties and foster cooperation in the future.

The weight of English-language literature is compounded by another set of lists: a series of lists of (untranslated) works written in English that cover from pre-schoolers to young adults and adults. Most of these titles are readers or simplified versions of traditional stories. There are no such lists for titles originally written in any other language, which confirms the public policy trend of promoting English to the detriment of other foreign languages.

\section{Conclusions and further work}

Ten years ago, Mélitz successfully argued that "the dominance of English threatens the accumulation of capital in the form of literature" (Mélitz 2007, 212). Market pressures make it almost impossible for publishers to place a bet on foreign and largely unknown titles: only those works that have proved to be successful elsewhere find a way to be translated somewhere else. The US and the UK publishing markets are powerful makers of best-sellers, which they then gladly export to other countries. I do not intend to 
say that this is necessarily bad, but simply that our society calls for more diversity.

This study can be used to raise public awareness to Englishlanguage imperialism through cultural goods. Its results might be used to discuss whether new policies could be designed to promote multiculturalism, and even multilingualism, by introducing children to literature from other different countries. This would entail contacting with different cultures and worldviews, which would contribute to raising broad-minded children.

However, multilingualism is still not widely promoted in Portugal. Although younger generations are more languageaware, much has to be done to stir the population into effectively investing in their linguistic skills. In 2013, only 35 per cent of primary pupils studied a foreign language in Portugal, a ridiculously low number when compared with the 81.7 per cent average of the EU (Eurostat 2015).

In the future, expanding this research to include the whole PNL would be important to confirm the trend of English dominance we saw in the third cycle of schooling. This would entail analysing several other lists, which include the pre-schoolers (aged 6 months to 5 years), the whole primary education (from 6 to 9), and secondary education until 18 years old. There is also a list for adults, which could provide further basis for analysis and comparison.

Another important aspect that was not considered in this study needs to be addressed: What is the source language for the translation of books written in less common languages? Based on the Eurobarometer study (EC 2012), from the small percentage of respondents to the survey who answered that they spoke at least one foreign language well enough to be able to have a conversation (only 39 per cent which compares with the 54 per cent average of all the 27 EU countries), English, French, German, Spanish, and Russian could be considered common languages in Portugal. Besides these languages, I would also include Italian in the list of commonly spoken languages in Portugal, since it is a Romance language and therefore easier to learn and to be used as a source 
language for translation. I also believe Galician will not pose any difficulty to a Portuguese translator and that there is a fair number of Ancient Greek translators in the country. This leaves out the four books written in Swedish, the book written in Chinese, the book written in Basque, and the book written in Hebrew. Were all these books translated from their original languages or were they translated from an intermediary, more common, language? If so, which was that language? In many cases, the answer to this question will probably be English, since works written in peripheral languages often have access to the mainstream via a central or hypercentral language (Heilbron 1999, Sapiro 2010). This clearly contributes to increase the power of the English language in the international translation market.

Given that "torturing bodies is less effective than shaping minds" (Castells 2007, 238), I believe translation is indeed an instrument of power. As such, more should be done to diversify the source languages and expose Portuguese readers to a wider variety of cultures, while at the same time working towards promoting Portuguese cultural goods abroad.

\section{Acknowledgements}

This research has been partially financed by Portuguese national funding through FCT - Fundação para a Ciência e a Tecnologia as part of the project Centro de Linguística da Universidade Nova de Lisboa - UID/LIN/03213/2013. 


\section{References}

Bielsa, Esperança. "Globalisation and translation: A theoretical approach." Language and Intercultural Communication 5.2 (2005): 131-144.

Bielsa, Esperança. "Beyond Hybridity and Authenticity: Globalisation, Translation and the Cosmopolitan Turn in the Social Sciences." Synthesis 4 (2012): 17-35.

Castells, Manuel. "Communication, Power and Counter-power in the Network Society." International Journal of Communication 1.1 (2007): 238-266.

Donahaye, Jasmine. "Three percent? Publishing data and statistics on translated literature in the United Kingdom and Ireland." Mercator Institute for Media, Languages and Cultures, Aberystwyth University, Wales, 2012.

De Swaan, Abram. "The emergent world language system: An introduction." International Political Science Review/Revue Internationale de Science Politique 14.3 (1993): 219-226.

European Commission (2012). "Europeans and their languages." Special Eurobarometer 386. Directorate-General for Communication. Available at http:// ec.europa.eu/public_opinion/archives/ebs/ebs_386_en.pdf [29-06-2016].

Eurostat (2015). "News release, 164/2015." Eurostat Press Office. Available at http://ec.europa.eu/eurostat/documents/2995521/7008563/3-24092015-AP-EN. pdf $[29 / 06 / 2016]$.

Heilbron, Johan. "Towards a Sociology of Translation Book Translations as a Cultural World-System.” European Journal of Social Theory 2.4 (1999): 429444.

Heilbron, Johan. "Structure and dynamics of the world system of translation." UNESCO, International Symposium Translation and Cultural Mediation (2010): $22-23$. 
INE - Instituto Nacional de Estatística. "Estatísticas da Cultura 2013." Instituto Nacional de Estatística, Lisbon, 2014.

INE - Instituto Nacional de Estatística. "Estatísticas da Cultura 2014." Instituto Nacional de Estatística, Lisbon, 2015.

Mélitz, Jacques. "The impact of English dominance on literature and welfare." Journal of Economic Behavior \& Organization 64.2 (2007): 193-215.

Mélitz, Jacques. "English as a Global Language." Working Paper, No. 2015-05. Heriot-Watt University, Edinburgh, 2015.

Parks, Gerald. "Towards a Sociology of Translation". Revista Internazionale di Tecnica della Traduzione/International Journal of Translation 3 (1998): 25-35.

Perona, Mathieu. "How Broadcasting Quotas Harm Program Diversity". Munich Personal RePEc Archive. 2010.

Phillipson, R. Linguistic Imperialism. Oxford: Oxford University Press, 1992.

Pym, Anthony. "Globalization and the Politics of Translation Studies." Meta: Journal des traducteursMeta:/Translators' Journal 51.4 (2006): 744-757.

Sapiro, Gisèle. "French Literature in the World System of Translation." Trans. Jody Gladding. In French Global: A New Approach to Literary History. Edited by Christie McDonald and Susan Rubin Suleiman. New York: Columbia University Press, 2010. 298-319.

. "Translation as a Weapon in the Struggle against Cultural Hegemony in the Era of Globalization." Bibliodiversity - Translation and Globalization (Feb. 2014): 31-39.

UNESCO. Universal Declaration on Cultural Diversity. World Summit on Sustainable Development, Johannesburg, 26 August to 4 September 2012. Available at http://unesdoc.unesco.org/images/0012/001271/127162e.pdf [29/06/2016]. 
Venuti, Lawrence. The Scandals of Translation: Towards an Ethics of Difference. London and New York: Routledge, 1998.

Werner, Camilla. Literary Translation Flow from Brazil to Abroad: Six Case Studies. MA thesis. Leiden University, 2009.

Recebido em: 05/06/2016 Aceito em: 13/09/2016 Publicado em janeiro de 2017 